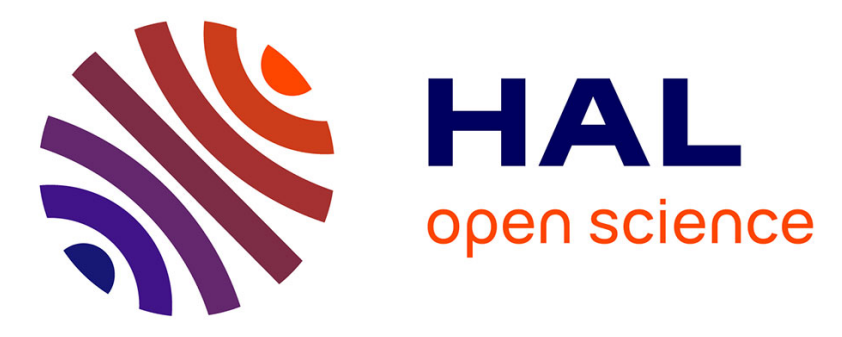

\title{
Corrosion behaviour of brazed multilayer material AA4343/AA3003/AA4343: Influence of coolant parameters
}

Séverin Tierce, Nadine Pébère, Christine Blanc, Christian Casenave, Georges Mankowski, Herveline Robidou

\section{To cite this version:}

Séverin Tierce, Nadine Pébère, Christine Blanc, Christian Casenave, Georges Mankowski, et al.. Corrosion behaviour of brazed multilayer material AA4343/AA3003/AA4343: Influence of coolant parameters. Corrosion Science, 2007, vol. 49, pp. 4581-4593. 10.1016/j.corsci.2007.04.013 . hal-00808899

\section{HAL Id: hal-00808899 https://hal.science/hal-00808899}

Submitted on 8 Apr 2013

HAL is a multi-disciplinary open access archive for the deposit and dissemination of scientific research documents, whether they are published or not. The documents may come from teaching and research institutions in France or abroad, or from public or private research centers.
L'archive ouverte pluridisciplinaire HAL, est destinée au dépôt et à la diffusion de documents scientifiques de niveau recherche, publiés ou non, émanant des établissements d'enseignement et de recherche français ou étrangers, des laboratoires publics ou privés. 


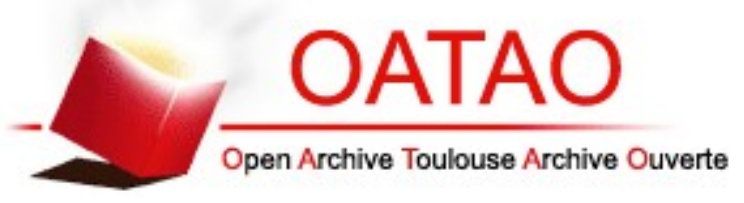

\section{Open Archive Toulouse Archive Ouverte (OATAO)}

OATAO is an open access repository that collects the work of Toulouse researchers and makes it freely available over the web where possible.

This is an author-deposited version published in: http://oatao.univ-toulouse.fr/ Eprints ID : 2422

To link to this article :

URL : http://dx.doi.org/10.1016/j.corsci.2007.04.013

To cite this version : Tierce, Séverin and Pébère, Nadine and Blanc, Christine and Casenave, C. and Mankowski, Georges and Robidou, H. ( 2007) Corrosion behaviour of brazed multilayer material AA4343/AA3003/AA4343: Influence of coolant parameters. Corrosion Science, vol. 49 ( $\left.\mathrm{n}^{\circ} 12\right)$. pp. 4581-4593. ISSN 0010-938X

Any correspondence concerning this service should be sent to the repository administrator:staff-oatao@inp-toulouse.fr 


\title{
Corrosion behaviour of brazed multilayer material AA4343/AA3003/AA4343: Influence of coolant parameters
}

\author{
S. Tierce ${ }^{\mathrm{a}, \mathrm{b}}, \mathrm{N}$. Pébère ${ }^{\mathrm{a}, *}, \mathrm{C}$. Blanc $^{\mathrm{a}}, \mathrm{C}$. Casenave ${ }^{\mathrm{b}}$, \\ G. Mankowski ${ }^{\mathrm{a}}$, H. Robidou ${ }^{\mathrm{b}}$ \\ a CIRIMAT, UMR CNRS 5085, ENSIACET, 31077 Toulouse cedex 4, France \\ ${ }^{\mathrm{b}}$ Valeo Engine Cooling, BP 14, 72210 La Suze sur Sarthe, France
}

\begin{abstract}
This paper is the second part of a work devoted to corrosion in brazed AA4343/AA3003/AA4343 materials on the water side of automotive heater cores. In the first part of the study [S. Tierce, N. Pébère, C. Blanc, C. Casenave, G. Mankowski, H. Robidou, Electrochim. Acta 52 (2006) 1092], corrosion initiation in the surface layer (i.e. the residual cladding) has been investigated. It has been associated to defective sites in the passive film covering the alloy. The defective sites are linked to $\alpha-\mathrm{Al}(\mathrm{Mn}, \mathrm{Fe}) \mathrm{Si}$ particles built up during brazing process. Interactions between $\alpha$-Al( $\mathrm{Mn}, \mathrm{Fe}) \mathrm{Si}$ particles and the matrix are responsible for the observed behaviour. The present study focuses on the propagation of corrosion through the material in neutral water-ethylene glycol mixtures with and without chlorides. Comparison of the electrochemical behaviour of the three layers of the brazed material (i.e. the residual cladding, the "band of dense precipitates (BDP)" and the core material) revealed that the residual cladding was nobler than the BDP and the core material and thus that the corrosion should propagate through the inner layers due to galvanic coupling: the inner layers constitute the anode and the residual cladding the cathode. Increasing the ethylene glycol content in the water-ethylene glycol mixture decreased the rate of consumption of the materials whereas addition of chloride ions increased it. Mass variation measurements of brazed material in different solutions containing the degradation products of ethylene glycol showed that only glycolate ions

\footnotetext{
* Corresponding author.

E-mail address: Nadine.Pebere@ensiacet.fr (N. Pébère).
} 
had a slight detrimental effect. Corrosion tests performed in heater core tubes allowed the propagation mechanisms to be confirmed.

Keywords: A. Aluminium alloys; B. Polarization curves; C. Corrosion potential; C. Galvanic couple

\section{Introduction}

Aluminium alloys are commonly used for heat exchangers in the automotive industry due to an interesting combination of properties (low density, good thermal conductivity, satisfactory mechanical properties and relatively good corrosion resistance). Since the mid-1990, the trend in automotive heat exchangers has been to replace mechanical assembly by brazing of aluminium alloys mainly to decrease the cost. Aluminium alloys used for brazing consist of multilayer materials composed of a $3 \mathrm{XXX}$ core alloy clad on one or both sides with a 4XXX alloy. The coolants used in automotive cooling loops are mainly composed of water and ethylene glycol ( $\mathrm{pH}$ between 7 and 8 ). The working temperature range depends on the geographic locations, although the maximum coolant temperature is always about $100{ }^{\circ} \mathrm{C}$, the minimum can drop down to about $-30{ }^{\circ} \mathrm{C}$. Chloride ions are often found in the cooling loops. In addition, organic salts such as glycolate, formate, acetate, and oxalate resulting from degradation of ethylene glycol are also encountered in degraded coolants. Occasionally, during service, perforation of the heater core tubes occurs due to corrosion.

The objective of the present study is to understand the mechanisms of corrosion propagation through the wall of the heater core tubes, taking into account the parameters of the coolants (ethylene glycol content, presence of chloride and degradation products of ethylene glycol, temperature).

The parts to be brazed were composed of AA4343/AA3003/AA4343 sandwich sheets where AA3003 is an Al-Mn base alloy and AA4343 an Al-Si base alloy. During the brazing process, the parts to be assembled are briefly heated to a temperature between the melting temperatures of the two alloys. The brazing modifies the geometry and the microstructure of the cladding as well as the microstructure of the AA3003 core. In previous studies [2,3], an overview of solidification and the phase transformations occurring during brazing was presented with particular attention paid to phase identification. Resolidification of AA4343 leads to the formation of both brazed joints at the contact points between the different parts and of a residual thin layer of cladding covering the flat surfaces of the parts remote from the brazing joints. Three phases were identified in both areas: (Al), Si and $\alpha-\mathrm{Al}(\mathrm{Fe}, \mathrm{Mn}) \mathrm{Si}$. The Al-Si equilibrium phase diagram [4] suggests that the solid solution of aluminium contains about $1 \%$ silicon. Several studies $[2,3,5-7]$ also showed the formation of a "band of dense precipitates (BDP)" in the AA3003 core material resulting from the solid-state precipitation of small nodules of $\alpha-\mathrm{Al}(\mathrm{Fe}, \mathrm{Mn}) \mathrm{Si}$ induced by the diffusion of $\mathrm{Si}$ from the liquid film to the core material. For the core material unaffected by Si diffusion, previous metallurgical analysis $[2,8]$ of AA3003 showed that the $\mathrm{Al}_{6}(\mathrm{Mn}, \mathrm{Fe})$ phase was the main heterogeneity in the aluminium matrix. Sometimes, the $\alpha-\mathrm{Al}(\mathrm{Fe}, \mathrm{Mn}) \mathrm{Si}$ phase is also present after heat treatment [8]. On the basis of the Al-Mn equilibrium phase diagram [4], the aluminium phase should contain about $0.7 \%$ of manganese in the core material.

In a recent work [1], it was shown that corrosion initiation in the residual cladding in contact with the coolant was linked to particle/matrix interactions, It has been clearly 
demonstrated that corrosion initiation sites are constituted by particles of $\alpha$-Al( $\mathrm{Fe}, \mathrm{Mn}) \mathrm{Si}$ phase. It has also been shown that Si particles do not participate to the progression of corrosion. This result is in agreement with the work of Meijers [9] showing that although silicon is nobler than aluminium, the current density of oxygen reduction on silicon is too low to make Si particles become active cathodic sites.

Corrosion propagation in the multilayer structure of the brazed material can be considered as a coupling between three layers containing different phases, namely the residual cladding (Al(1\% Si), Si and $\alpha-\mathrm{Al}(\mathrm{Fe}, \mathrm{Mn}) \mathrm{Si}$ phases), the BDP (Al(0.7\% $\mathrm{Mn}), \mathrm{Al}_{6}(\mathrm{Mn}, \mathrm{Fe})$ and $\alpha-\mathrm{Al}(\mathrm{Fe}, \mathrm{Mn}) \mathrm{Si}$ phases $)$ and the core material $\left(\mathrm{Al}(0.7 \% \mathrm{Mn}), \mathrm{Al}_{6}(\mathrm{Mn}, \mathrm{Fe})\right.$ phases $)$. Few studies have been devoted to corrosion propagation in brazed alloys. Marshall et al. [6] and Benedictus et al. [7] have estimated that the corrosion propagates in the BDP. In contrast, the study of Mondolfo [10] devoted to the electrochemical behaviour of different solid solutions of aluminium suggests than $\mathrm{Al}(1 \% \mathrm{Si})$ is nobler than $\mathrm{Al}(1 \%$ $\mathrm{Mn})$. Taking into account that previous studies have shown that the presence of $\mathrm{Si}$ $[9,10]$, of $\mathrm{Al}_{6}(\mathrm{Mn}, \mathrm{Fe})[11,12]$ and of low amounts of $\alpha-\mathrm{Al}(\mathrm{Fe}, \mathrm{Mn}) \mathrm{Si}$ (volume fraction lower than $1 \%$ ) [9] only have a slight influence on the value of the corrosion potential of the alloys in which they occur, the classification of the corrosion potential of the different layers of the brazed material should depend on the composition of the solid solution of aluminium in the different regions of the material: Si-rich nobler than Si-poor solid solution of aluminium. In this case, the order of the corrosion potentials should be different from the classification proposed by Marshall et al. [6] and Benedictus et al. [7], i.e., $E_{\text {corr }}$ (core material $)<E_{\text {corr }}(\mathrm{BDP})<E_{\text {corr }}$ (residual cladding).

In the present study, the electrochemical behaviour of the different layers was firstly investigated in different conditions to clarify which of the three layers was the noblest. Due to the context of the study, it was necessary to carry out the experiments in neutral solutions and to take into account the influence of parameters related to cooling liquids such as ethylene glycol content and the presence of chloride ions. The previous study devoted to the corrosion initiation [1] showed that the attacks were favoured at $90{ }^{\circ} \mathrm{C} \mathrm{com-}$ pared to the results obtained at lower temperatures. As a consequence, electrochemical measurements (plots of the polarisation curves), used to characterise the corrosion resistance of the different layers, were only carried out at $90^{\circ} \mathrm{C}$. Mechanisms of corrosion propagation in the brazed material are discussed. In the second part of the study, the influence of the species coming from the coolant (chloride, glycolate, formate, acetate, and oxalate) was investigated on the basis of immersion tests and mass variation measurements. It can be emphasised that electrochemical measurements were not performed in the presence of the carboxylate ions due to their oxidation or reduction under polarisation. In the third part of the study, corrosion tests were carried out on heater core tubes.

\section{Experimental}

The chemical composition of AA3003* and AA4343 before brazing is shown in Table 1. The microstructure of the alloys was examined after brazing with an optical microscope (OM) and after corrosion initiation in the residual cladding with a JSM 6400 scanning electron microscope (SEM).

The study of corrosion propagation in neutral solutions was performed plotting the polarisation curves of the three layers of the material. The influence of the ethylene glycol content and the presence of chloride ions on the electrochemical behaviour were 
Table 1

Chemical composition of the $\mathrm{Al}$ alloys (wt.\%)

\begin{tabular}{lllllll}
\hline & $\mathrm{Si}$ & $\mathrm{Mn}$ & $\mathrm{Fe}$ & $\mathrm{Cu}$ & $\mathrm{Zn}$ & $\mathrm{Al}$ \\
\hline AA3003 $^{\mathrm{a}}$ & 0.08 & 1.10 & 0.19 & 0.19 & 0.10 & $\mathrm{Bal}$. \\
AA4343 & 7.90 & 0.01 & 0.09 & 0.11 & 0.09 & Bal. \\
\hline
\end{tabular}

${ }^{a}$ Modified AA3003 with copper enrichment.

investigated. Electrochemical measurements were first carried out in a neutral low corrosive solution containing $0.1 \mathrm{M} \mathrm{Na}_{2} \mathrm{SO}_{4}$ exposed to air at $90{ }^{\circ} \mathrm{C}$. Sodium sulphate was chosen to increase the conductivity of the solution and for its low corrosiveness toward aluminium alloys. A second set of measurements was also carried out at $90{ }^{\circ} \mathrm{C}$ but in solutions containing $0.1 \mathrm{M} \mathrm{Na}_{2} \mathrm{SO}_{4}$ to which $0.01 \mathrm{M} \mathrm{NaCl}$ had been added. This chloride content was chosen since it is typical of amounts measured in degraded liquids coming from service. Experiments were also carried out in $0.1 \mathrm{M}$ sodium sulphate water-ethylene glycol mixtures containing 30\% and $80 \%$ ethylene glycol.

For the electrochemical experiments, three types of working electrode were prepared; residual cladding, BDP and core material unaffected by silicon diffusion. The residual cladding electrodes were cut directly in brazed heater core tubes. They were electrically connected by soldering to a copper wire. The assemblies were then hot embedded in a phenolic resin. They were cleaned by immersion in an ultrasonic bath to avoid damage to the superficial layer. A varnish was applied at the border of the electrode to prevent cavernous corrosion at the electrode/resin interface. The BDP electrodes were prepared from brazed AA4343/AA3003*/AA4343 sandwich sheets. Electrical connection was achieved by soldering to a copper wire and the assembly hot embedded in a phenolic resin. Before electrochemical measurements, the BDP electrodes were mechanically polished down to $1 \mu \mathrm{m}$ diamond paste. A varnish was also applied around the electrode to prevent corrosion at the electrode/resin interface. As the specimens of BDP were very thin, each BDP electrode was only used once. The electrodes of the inner portion of the core material (unaffected by silicon diffusion) were prepared from AA3003* sheets submitted to a brazing cycle in an industrial furnace. Connection, embedding, polishing and varnishing procedures were performed in the same way as for the BDP. Electrochemical measurements were performed with a three-electrode corrosion cell. The electrolyte was slowly circulated from a thermostated auxiliary container to the corrosion cell. The auxiliary electrode was a platinum plate and the reference electrode a saturated $\mathrm{Hg}_{2} \mathrm{SO}_{4} / \mathrm{K}_{2} \mathrm{SO}_{4}$ electrode (SSE). The polarisation measurements were carried out after $1 \mathrm{~h}$ immersion at open circuit potential using an Autolab PGSTAT12 at a potential sweep rate of $1 \mathrm{~V} / \mathrm{h}$ from the cathodic domain towards the anodic one.

Mass variation measurements after immersion in neutral solutions were carried out at room temperature. Samples were immersed in different solutions: (i) in deionised water, (ii) in aqueous solution containing $350 \mathrm{ppm}(0.01 \mathrm{M}) \mathrm{NaCl}$ without any additives, (iii) in solution containing $350 \mathrm{ppm}(0.01 \mathrm{M}) \mathrm{NaCl}$ in the presence of one of the ethylene glycol degradation products $(500 \mathrm{ppm}$ glycolate ions or $250 \mathrm{ppm}$ of formate ions or $100 \mathrm{ppm}$ acetate ions or $50 \mathrm{ppm}$ oxalate ions) and (iv) in solution containing $350 \mathrm{ppm}(0.01 \mathrm{M}) \mathrm{NaCl}$ in the presence of all the ethylene glycol degradation products at the above concentrations. Solutions (iii) and (iv) were prepared with the carboxylic acids corresponding to the carboxylates and the $\mathrm{pH}$ was adjusted between 6 and 7 at the beginning of the experiments with 
$0.1 \mathrm{M} \mathrm{NaOH}$ solution. In this range of $\mathrm{pH}$, the stable species were the carboxylates in the four cases. It is noteworthy that the $\mathrm{pH}$ showed low variation with time during the experiments. Ten samples were immersed for each experimental condition, one being taken for analysis every week. It was weighed with its corrosion products after drying and then weighed a second time after stripping off the corrosion products with a $75 \%$ solution of $\mathrm{H}_{3} \mathrm{PO}_{4}$.

Finally, corrosion tests were carried out with two different solutions selected in view of the results obtained. The tests consisted in circulating the test solutions in commercial heat exchangers. The average fluid velocity was $0.3 \mathrm{~m} \mathrm{~s}^{-1}$ in the tubes of the heater cores.

\section{Results}

\subsection{Observation of the multilayer structure of the brazed material}

Fig. 1 shows an OM observation of a sample section after brazing and reveals the heterogeneous structure of the material. The residual cladding appears in white on both sides of the section, the band of dense precipitates (BDP) is observed in darker grey just under the residual cladding and the core material unaffected by Si diffusion is seen in the central portion.

\subsection{Observation of corrosion initiation}

Fig. 2 shows a SEM observation of corrosion initiation in the residual cladding after an immersion of $150 \mathrm{~h}$ in deionised water. The attacks occur in the valleys separating the $\mathrm{Al}$ grains where the $\alpha-\mathrm{Al}(\mathrm{Fe}, \mathrm{Mn}) \mathrm{Si}$ particles are mainly concentrated. This observation is in good agreement with the study of the corrosion initiation process [1].
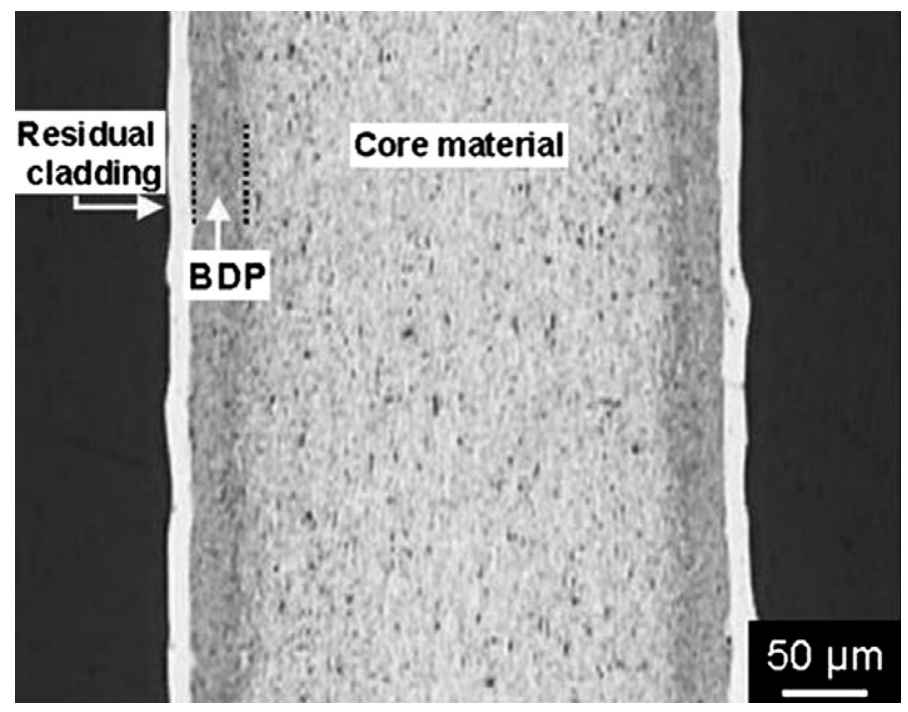

Fig. 1. Optical microscope $(\mathrm{OM})$ observation of a section of the brazed material showing the layered structure observed after brazing (etched for $60 \mathrm{~s}$ in Keller's reagent). 


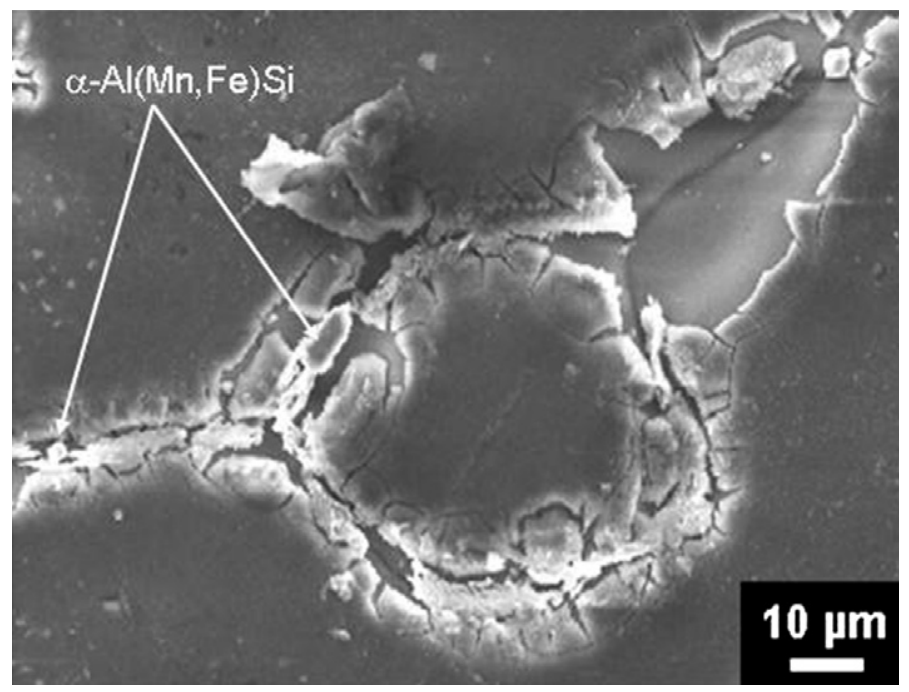

Fig. 2. Scanning electron microscope (SEM) observations after $150 \mathrm{~h}$ of immersion of the brazed material in deionised water showing the corrosion initiation in the residual cladding on the scale of intergranular valleys.

\subsection{Electrochemical measurements}

The polarisation curves for the three layers of the brazed material are presented in the same graph for a given experimental condition.

\subsubsection{Polarisation curves without ethylene glycol}

Fig. 3 presents the curves obtained for the three layers in $0.1 \mathrm{M} \mathrm{Na}_{2} \mathrm{SO}_{4}$ solution without ethylene glycol at $90^{\circ} \mathrm{C}$ without (Fig. 3a) and with $0.01 \mathrm{M}$ chloride ions (Fig. 3b). Without chloride, a progressive increase of the anodic current density of the residual cladding is observed as the potential increases (Fig. 3a). The curve obtained for the BDP presents a large anodic plateau. A slight increase of the anodic current density is noted at the end of the plateau when the potentials are beyond $-0.6 \mathrm{~V} / \mathrm{SSE}$. The anodic curves obtained for the core material unaffected by silicon diffusion present a passivation plateau over the entire anodic potential range studied.

The anodic curves revealed that the residual cladding was the most reactive of the three layers constituting the brazed material. It was shown previously that the increase of the anodic current densities observed for the residual cladding was due to the reactivity of the $\alpha-\mathrm{Al}(\mathrm{Fe}, \mathrm{Mn}) \mathrm{Si}$ particles [1]. This behaviour has been called "defective passivation". Conversely, it is observed that the BDP and the core material unaffected by silicon diffusion passivate at potentials close to the corrosion potential. The increase of the anodic current densities observed for the BDP at potentials higher than $-0.6 \mathrm{~V} / \mathrm{SSE}$ suggests that the protective properties of the passive film formed for the BDP are lower than those of the film formed on the alloy AA3003 unaffected by silicon diffusion. It has been shown that silicon diffusion induces solid-state precipitation of nodules of $\alpha-\mathrm{Al}(\mathrm{Mn}, \mathrm{Fe}) \mathrm{Si}$ phase in the BDP [2,3]. These particles have previously been reported to be reactive [1], thus the behaviour observed for potentials higher than $-0.6 \mathrm{~V} / \mathrm{SSE}$ should be related to the 

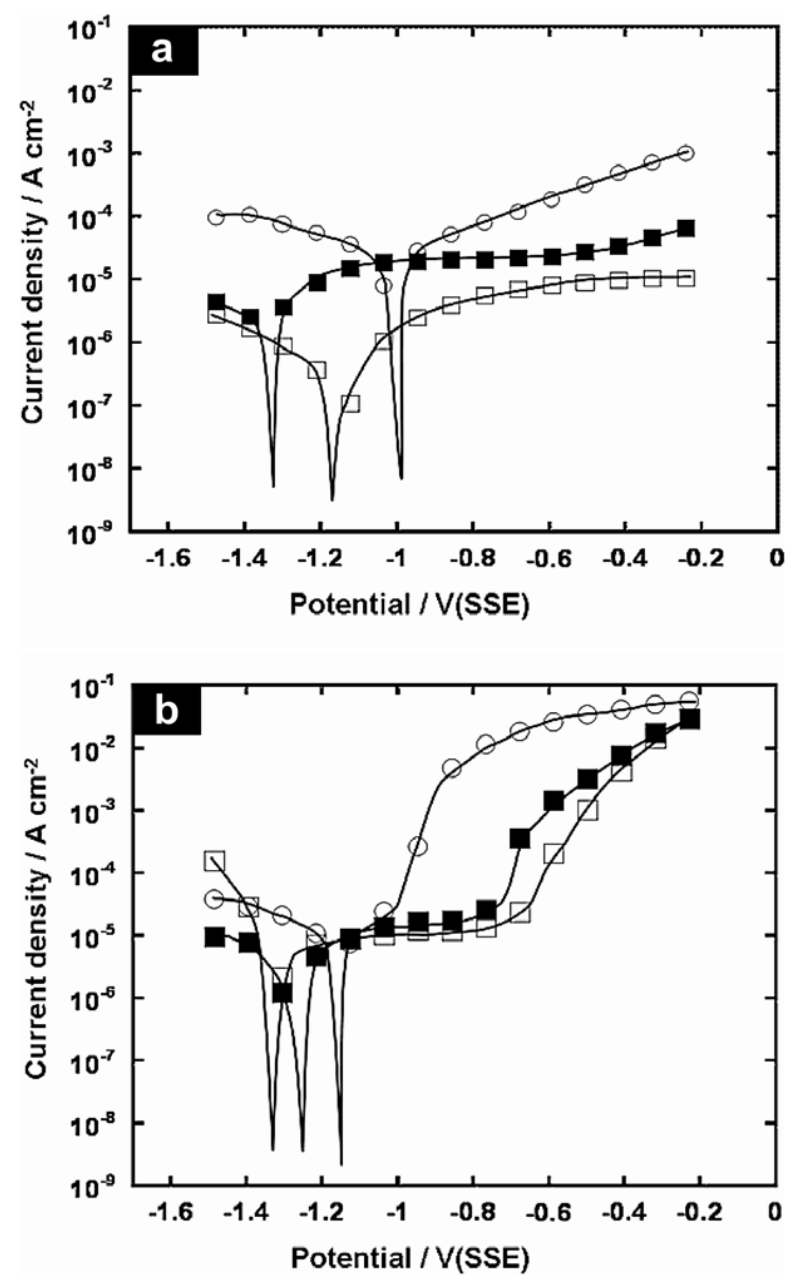

Fig. 3. Polarisation curves for the residual cladding $(\bigcirc)$, the $\mathrm{BDP}(\square)$, and the core material $(\square)$ in $0.1 \mathrm{M} \mathrm{Na}_{2} \mathrm{SO}_{4}$ aqueous solutions at $90^{\circ} \mathrm{C}$ (a) without chloride ion and (b) with $0.01 \mathrm{M} \mathrm{NaCl}$.

presence of small $\alpha-\mathrm{Al}(\mathrm{Mn}, \mathrm{Fe}) \mathrm{Si}$ nodules in the BDP. The low surface area covered by these particles can explain why the anodic current densities, characteristic of their reactivity, only exceeded the passivation plateau for potentials higher than $-0.6 \mathrm{~V} / \mathrm{SSE}$. Passivation of the alloy AA3003 (core material) shown in Fig. 3a is well known to occur [10-12].

Fig. $3 \mathrm{~b}$ shows the influence of the addition of $0.01 \mathrm{M} \mathrm{NaCl}$ on the polarisation curves. The anodic parts of the curves exhibit two domains for each layer. For the residual cladding, the first domain is between the corrosion potential and $-0.95 \mathrm{~V} / \mathrm{SSE}$ whereas, the second domain corresponds to potentials higher than $-0.95 \mathrm{~V} / \mathrm{SSE}$. In the first domain, the anodic branch is characteristic of "defective passivation" with a progressive increase of the current densities as the potential increases. In the second domain, an abrupt increase of the current densities, characteristic of pitting corrosion, is observed. For the BDP, the anodic domain of the polarisation curve obtained in $0.1 \mathrm{M} \mathrm{Na}_{2} \mathrm{SO}_{4}+0.01 \mathrm{M} \mathrm{NaCl}$ can 
also be divided into two parts. In the first domain, between the corrosion potential $(-1.25 \mathrm{~V} / \mathrm{SSE})$ and $-0.75 \mathrm{~V} / \mathrm{SSE}$, a well-defined passivation plateau is observed with current densities close to $10^{-5} \mathrm{~A} \mathrm{~cm}^{-2}$. For potentials higher than $-0.75 \mathrm{~V} / \mathrm{SSE}$, the increase of the current densities is associated to pitting corrosion. It is noteworthy that the current densities related to pitting corrosion are lower than those measured for the residual cladding. The description of the anodic curve of the BDP is similar to that of the core material unaffected by silicon diffusion. Nevertheless, for the core material, the value of the pitting potential is slightly different $(-0.65 \mathrm{~V} / \mathrm{SSE})$ and the current densities associated to pitting corrosion are lower than those measured for the BDP.

\subsubsection{Polarisation curves in presence of ethylene glycol}

Fig. 4 presents the influence of two concentrations of ethylene glycol in $0.1 \mathrm{M} \mathrm{Na}_{2} \mathrm{SO}_{4}$ solutions at $90{ }^{\circ} \mathrm{C}: 30 \%$ (Fig. 4a) and 80\% (Fig. 4b). Fig. 4a shows anodic behaviour for
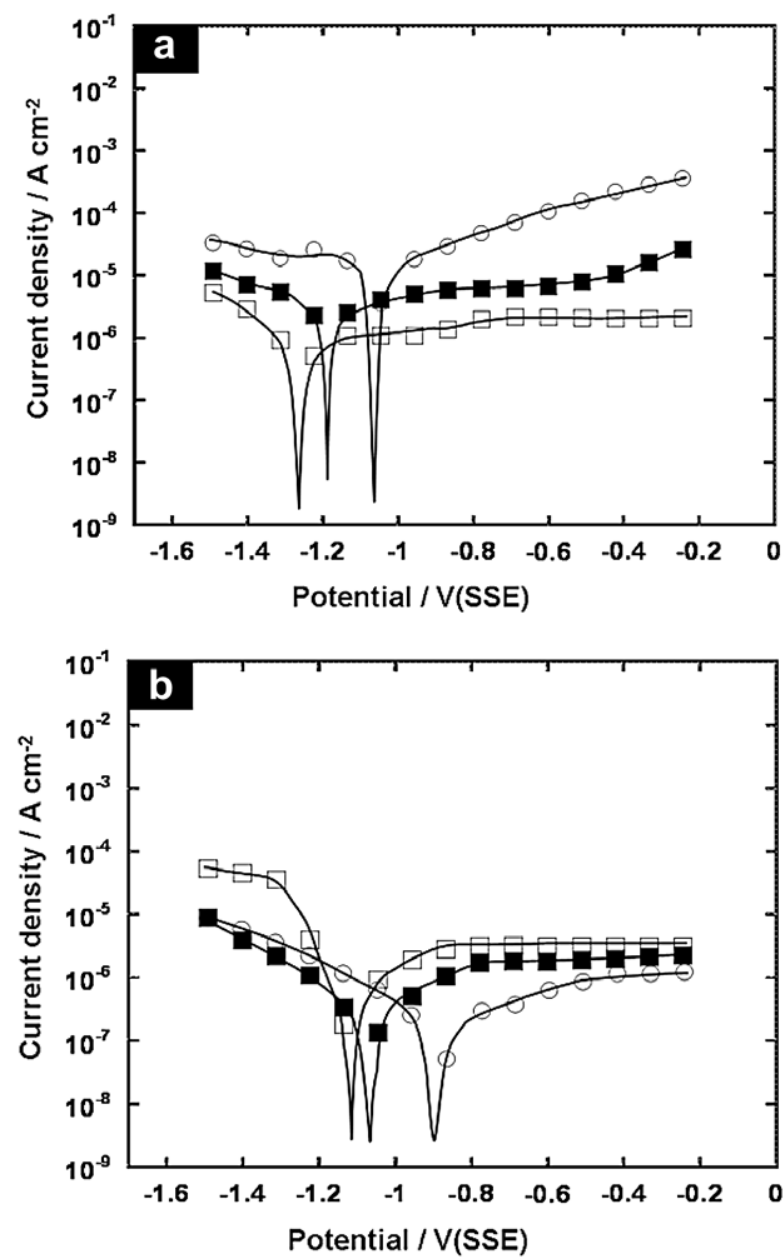

Fig. 4. Polarisation curves for the residual cladding $(\bigcirc)$, the $\mathrm{BDP}(\boldsymbol{\square})$, and the core material ( $\square$ ) in $0.1 \mathrm{M} \mathrm{Na}_{2} \mathrm{SO}_{4}$ water-ethylene glycol mixtures at $90{ }^{\circ} \mathrm{C}$ for ethylene glycol content of (a) $30 \%$ and (b) $80 \%$. 
the three layers similar to those observed without ethylene glycol (Fig. 3a). The curves only differ by the value of the anodic current densities with a slight decrease in the presence of $30 \%$ ethylene glycol compared to the values measured without ethylene glycol. This effect was previously observed for the electrochemical behaviour of the residual cladding [1].

With $80 \%$ ethylene glycol, Fig. $4 \mathrm{~b}$ reveals an anodic plateau for the three layers. This result shows that the three layers are in a passive state for a high ethylene glycol content. This is in good agreement with the transition between "defective passivation" and classic passivation previously described for the residual cladding [1] when the ethylene glycol content is higher than $60 \%$.

\subsubsection{Ranking the corrosion potentials}

Comparison of the corrosion potentials of the three layers obtained for the different experimental conditions reveals that the corrosion potential of the residual cladding is highest in all four solutions. This suggests that in the event of corrosion initiation in the residual cladding, coupling between the different layers should lead to anodic corrosion of the inner layers of the brazed material whereas the residual cladding will be the cathodic site. This result is in agreement with the classification of the corrosion potentials established by Mondolfo [10] $\left(E_{\text {corr }}(\mathrm{Al}(1 \% \mathrm{Mn}))<E_{\text {corr }}(\mathrm{Al}(1 \% \mathrm{Si}))\right)$. In fact, the results show that the layer with the solid solution of aluminium richest in silicon is the noblest layer. In the brazed material, the corrosion will propagate through the inner layers. Localised corrosion may be significant due to the large area of the cathodic surface compared to the anodic one. It is noteworthy that the corrosion rate will depend on the experimental conditions. For instance, the rate of consumption of the material will decrease in 0.1 $\mathrm{Na}_{2} \mathrm{SO}_{4}$ water-ethylene glycol if the ethylene glycol content increases. Moreover, local modifications such as $\mathrm{pH}$ decrease and chloride ion content increase should have a detrimental effect.

\subsection{Immersion tests and mass variation measurements}

Fig. 5 presents seven graphs showing the mass variation measurements of samples of brazed material immersed in different solutions.

Fig. 5a shows the variation of mass measured in deionised water without any additives. For immersion durations of less than one month, the corrosion of the brazed material varies randomly from one sample to another. The solution is not corrosive enough to reveal a tendency in corrosion progress. Thus, the six other measurements were performed with 350 ppm NaCl.

Fig. $5 \mathrm{~b}$ plots the results obtained in a $350 \mathrm{ppm} \mathrm{NaCl}$ solution. As expected in the presence of chloride, a progressive increase of the mass of the samples before stripping is observed. This can be related to the presence of aluminium hydroxides on the sample surface. After stripping, a mass loss of $0.003 \mathrm{~g} \mathrm{~cm}^{-2}$ is observed for the sample immersed for 49 days. The presence of chloride ions significantly increases the corrosion rate of the brazed material and leads to corrosion progress which is less random than that observed without chloride ions (Fig. 5a).

Fig. $5 \mathrm{c}$ presents the measurements performed in a solution containing $350 \mathrm{ppm}$ of $\mathrm{NaCl}$ and the four ethylene degradation products. Two main results can be stressed: there is no mass gain of the samples before stripping and the mass losses measured after stripping are one-third those measured without the ethylene glycol degradation products (Fig. 5b). 

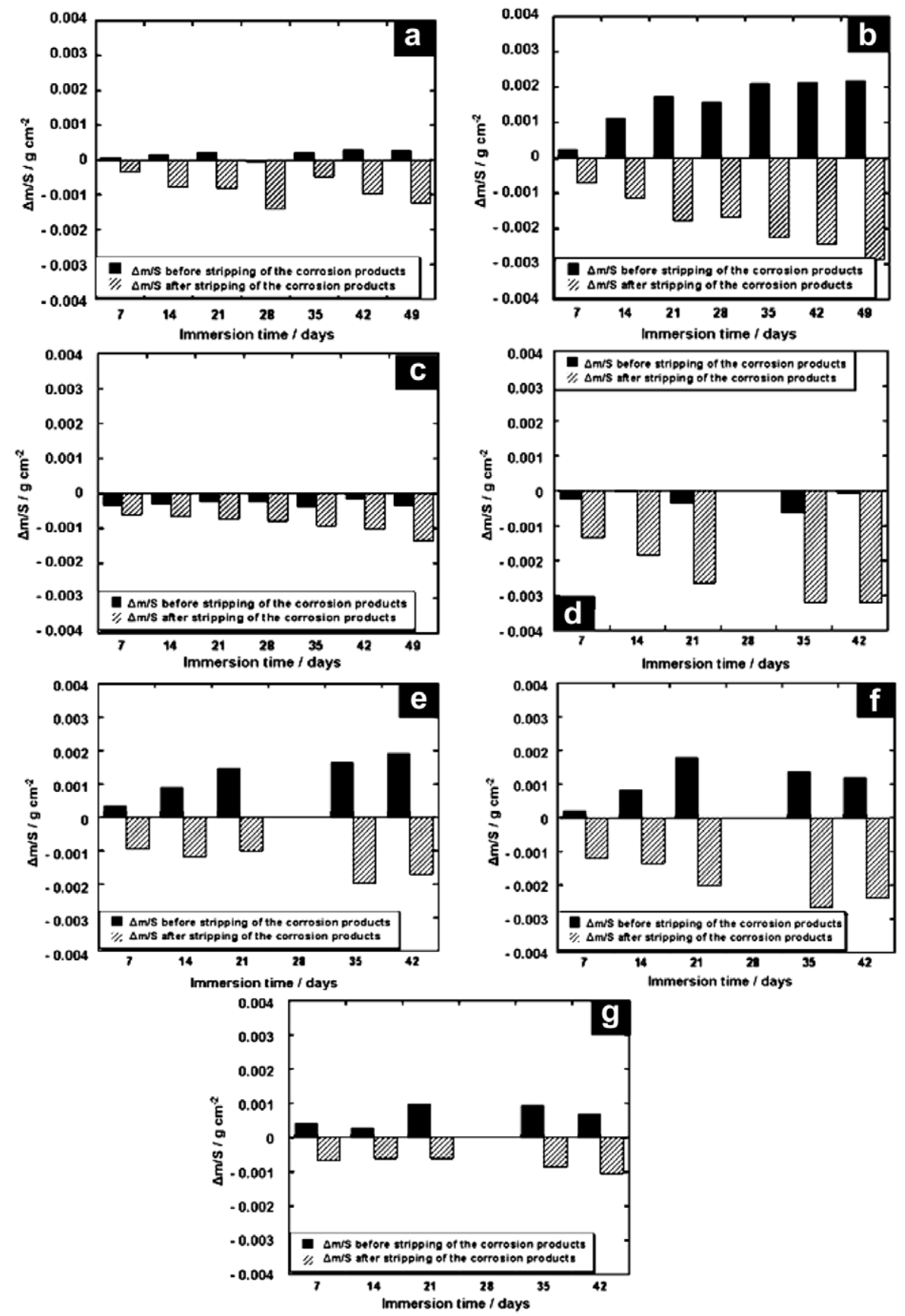

Fig. 5. Graphs showing the mass variation measurements of brazed material samples in different aqueous solutions: (a) without any additives, (b) with $350 \mathrm{ppm} \mathrm{NaCl}$, (c) with $350 \mathrm{ppm} \mathrm{NaCl}+500 \mathrm{ppm}$ glycolate $+250 \mathrm{ppm}$ formate $+100 \mathrm{ppm}$ oxalate $+50 \mathrm{ppm}$ acetate, (d) with $350 \mathrm{ppm} \mathrm{NaCl}+500 \mathrm{ppm}$ glycolate, (e) with $350 \mathrm{ppm} \mathrm{NaCl}+250 \mathrm{ppm}$ formate, (f) with $350 \mathrm{ppm} \mathrm{NaCl}+100 \mathrm{ppm}$ oxalate and (g) with $350 \mathrm{ppm}$ $\mathrm{NaCl}+50 \mathrm{ppm}$ acetate. 
These observations reveal that the presence of the four ethylene degradation products decreases the accumulation of the corrosion products at the sample surface and significantly reduces the corrosion rate of the brazed material. In order to separate the influence of the four ethylene glycol degradation products, experiments were performed with each of the carboxylates in the presence of $350 \mathrm{ppm} \mathrm{NaCl}$ (Fig. 5d-g). The decrease of corrosion product accumulation postulated from the results shown in Fig. 5c probably arises from the presence of the glycolate ions (Fig. 5d). The comparison of the weight loss after stripping in the presence of glycolate ions (Fig. 5d) and without carboxylates (Fig. 5b) also shows that the glycolates do not decrease the corrosion rate of the brazed material. The fall of the corrosion rate in the presence of the four ethylene glycol degradation products (Fig. 5c) seems to be mainly related to the presence of the acetate ions (Fig. 5g), Formate ions (Fig. 5e) and oxalate ions (Fig. 5f) do not significantly influence corrosion progress (slight decrease of the corrosion rate).

From the mass variation measurements in neutral media, it can be concluded that two configurations favour the corrosion attacks: a solution containing $350 \mathrm{ppm} \mathrm{NaCl}$ without additive where the corrosion products accumulate at the sample surface and a solution containing $350 \mathrm{ppm} \mathrm{NaCl}$ and glycolate ions where the corrosion products do not accumulate at the sample surface.

\subsection{Corrosion tests on heater core tubes}

To validate the corrosion propagation mechanisms deduced from the electrochemical measurements on the individual materials, tests were carried out on heater core tubes using a circulation loop. The conditions were selected based on the results obtained in the previous parts. The electrochemical measurements showed that the current densities were higher when the level ethylene glycol was lower in the electrolyte. As a consequence, the tests were carried out in mixtures containing $90 \%$ of water and $10 \%$ ethylene glycol. This configuration simulates conditions encountered in service where the coolants are degraded and contain residual ethylene glycol levels. A $350 \mathrm{ppm} \mathrm{NaCl}$ content was also used as the immersion test revealed that the presence of chloride ions favoured the progression of corrosion. The immersion tests also showed that the addition of $500 \mathrm{ppm}$ glycolate ions did not reduce the corrosion rate compared to those carried out without glycolate ions. Consequently, two solutions were tested: the first without glycolate ions and the second with $500 \mathrm{ppm}$ glycolate ions. It was previously demonstrated that increasing the temperature increased the corrosion rate [1]. In the present tests, the temperature was maintained at $70{ }^{\circ} \mathrm{C}$ which is a current condition encountered in the cooling loops of vehicles. The test durations were 14 days.

Fig. 6 presents OM observations of sections and surfaces of samples cut from corroded heater cores tubes. The section of the sample tested in the $90 \%$ water-containing mixture with $350 \mathrm{ppm} \mathrm{NaCl}$ (Fig. 6a) shows a cavity in the brazed material. In confirmation of the results of the immersion tests previously presented, the surface shows the presence of corrosion products (Fig. 6b). The section of the sample immersed in the mixture containing both $350 \mathrm{ppm} \mathrm{NaCl}$ and $500 \mathrm{ppm}$ glycolates (Fig. 6c) also shows the presence of a smooth cavity in the wall of the tube at the end of the test. The surface in Fig. 6d is shiny and metallic without corrosion products except around the point of attack occurring near the end of the test. 

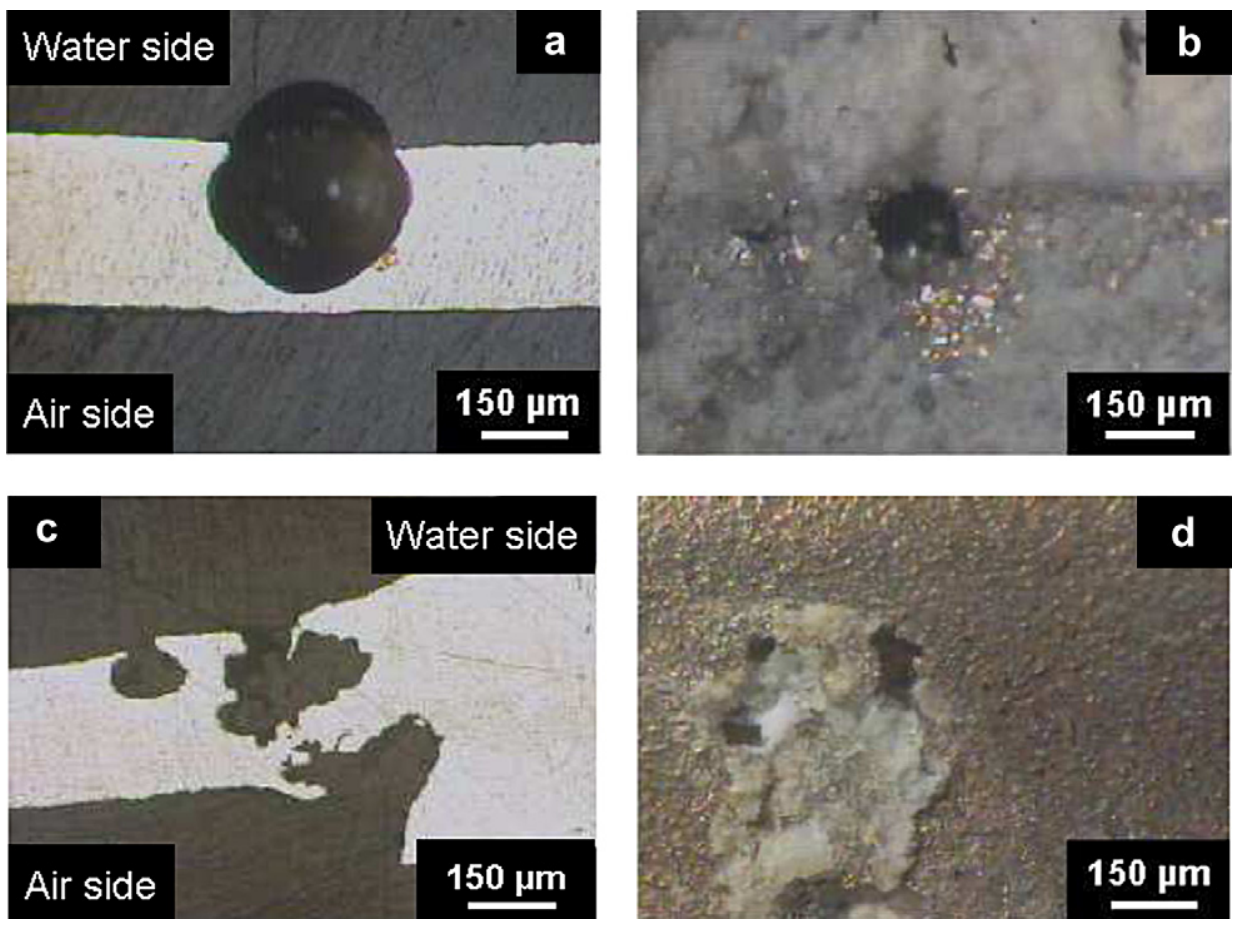

Fig. 6. OM observations of (a) the section and (b) the surface of a sample from a circulation test at $70{ }^{\circ} \mathrm{C}$ with a $90 \%$ water-containing mixture with $350 \mathrm{ppm} \mathrm{NaCl}$ and of (c) the section and (d) the surface of a sample from a circulation test at $70{ }^{\circ} \mathrm{C}$ with a $90 \%$ water-containing mixture with both $350 \mathrm{ppm} \mathrm{NaCl}$ and 500 ppm glycolate ions. Average solution velocity $=0.3 \mathrm{~m} \mathrm{~s}^{-1}$.

Good agreement was therefore seen with the mechanisms proposed for corrosion propagation in the brazed material: when the corrosion is initiated in the residual cladding, it propagates preferentially through the inner layers of the brazed material due to the difference in their corrosion potentials.

\section{Conclusion}

Corrosion propagation through the AA4343/AA3003/AA4343 sandwich was first investigated by plotting the polarisation curves for the three layers (i.e. the residual cladding, the "band of dense precipitates (BDP)" and the core material) in neutral water-ethylene glycol mixtures with and without chlorides. It was shown that the corrosion propagates through the brazed material due to galvanic coupling between the noble residual cladding layer and the less noble BDP layer and core material. Increasing the ethylene glycol content in the water-ethylene glycol mixture decreased the consumption rate of the brazed materials whereas addition of chloride ions increased it. In a second step, mass variation measurements of brazed material in different solutions containing the degradation products of ethylene glycol showed that only glycolate ions had a detrimental effect. Finally, corrosion tests were performed in heater core tubes and the propagation mechanisms previously proposed were confirmed. 


\section{Acknowledgement}

This work was carried out with financial and technical support from Valeo Engine Cooling (La Suze sur Sarthe, France).

\section{References}

[1] S. Tierce, N. Pébère, C. Blanc, C. Casenave, G. Mankowski, H. Robidou, Electrochim. Acta 52 (2006) 1092.

[2] S. Tierce, N. Pébère, C. Blanc, G. Mankowski, H. Robidou, D. Vaumousse, J. Lacaze, Int. J. Cast Met. Res. 18 (2005) 370.

[3] J. Lacaze, S. Tierce, M.-C. Lafont, Y. Thebault, N. Pébère, G. Mankowski, C. Blanc, H. Robidou, D. Vaumousse, D. Daloz, Mater. Sci. Eng. A 413-414 (2005) 317.

[4] L.F. Mondolfo, Aluminium Alloys: Structure and Properties, Butterworth \& Co, 1976.

[5] M. Nylen, U. Gustavsson, B. Hutchinson, A. Ortnas, Aluminium Alloys: Conference Proceedings of ICAA5, Materials Science Forum, vol. 217-222, Trans. Tech. Publication, Zurich, Switzerland, 1996, p. 1703.

[6] G.J. Marshall, R.K. Bolingbroke, A. Gray, Met. Trans. A 24 (1993) 1935.

[7] R. Benedictus, S.D. Meijers, A.J. Wittebrood, J.H.W. de Witt, Aluminium Alloys: Conference Proceedings of ICAA6, The Japan Institute of Light Metals, Toyohashi, Japan, 1998, p. 1577.

[8] Y.L. Li, L. Arnberg, Mater. Sci. Eng. A 347 (2003) 130.

[9] S. Meijers, Corrosion of aluminium brazing sheet, PhD thesis, Tehnische universiteit Delf, The Nederlands, 1997.

[10] L.F. Mondolfo, Light Metal Age 37 (1979) 20.

[11] M. Zamin, Corrosion 37 (1981) 627.

[12] W.A. Anderson, H.C. Stumpf, Corrosion 36 (1980) 212. 